\title{
Tri-generation System based on Municipal Waste Gasification, Fuel Cell and an Absorption Chiller
}

\author{
Giannis Katsaros ${ }^{* 1}$, Tuong-Van Nguyen ${ }^{2}$, Masoud Rokni ${ }^{3}$ \\ ${ }^{1}$ Department of Mechanical Engineering, Technical University of Denmark, Nils Koppels Allé, \\ Building 403, Kgs. Lyngby, Denmark \\ e-mail: Giannis.Katsaros@brunel.ac.uk \\ ${ }^{2}$ Department of Mechanical Engineering, Technical University of Denmark, Nils Koppels Allé, \\ Building 403, Kgs. Lyngby, Denmark \\ e-mail: tungu@mek.dtu.dk \\ ${ }^{3}$ Department of Mechanical Engineering, Technical University of Denmark, Nils Koppels Allé, \\ Building 403, Kgs. Lyngby, Denmark \\ e-mail: $\underline{\text { mr@mek.dtu.dk }}$
}

Cite as: Katsaros, G., Nguyen, T.-V., Rokni, M., Tri-generation System based on Municipal Waste Gasification, Fuel Cell and an Absorption Chiller, J. sustain. dev. energy water environ. syst., 6(1), pp 13-32, 2018, DOI: http://dx.doi.org/10.13044/j.sdewes.d5.0172

\begin{abstract}
The present work focuses on the design of a novel tri-generation system based on gasification of municipal solid wastes, a solid oxide fuel cell and an ammonia-water absorption chiller. Tri-generation systems can be implemented in buildings such as hospitals and hotels, where there is a continuous and large demand for electricity, heating and cooling. The system is modelled in Aspen Plus and the influence of different operating parameters on the system performance was studied. The findings suggest that low air equivalent ratios and high gasification temperatures enhance the overall system performance. Syngas cleaning with metal sorbents zinc oxide and sodium bicarbonate for the removal of hydrogen sulfide and hydrogen chloride concentrations proved to be very effective, reducing the concentration of contaminants to $<1 \mathrm{ppm}$ (part per million) levels. The possibility of covering the demand profiles of a specific building was also investigated: the system could fully meet the electricity and cooling demands, whereas the heat requirements could be satisfied only up to 55\%. Moreover, assuming 20 years of operation, the payback period was 4.5 years and the net present value exceeded 5 million euros.
\end{abstract}

\section{KEYWORDS}

Gasification, Solid oxide fuel cells, Tri-generation, Absorption chiller, Municipal waste, Syngas.

\section{INTRODUCTION}

Nowadays, waste management represents a matter of crucial importance for the society. According to Ruggiero [1], the total amount of wastes produced in EU, amounted to 2.3 billion tons in 2010 . The vast increase in the production of wastes

\footnotetext{
${ }^{*}$ Corresponding author
} 
during the last century is followed by negative consequences for the society and the environment. In particular, emissions of greenhouse gases constitute a serious threat for public health, whereas there is an important amount of raw materials that are lost due to the lack of efficient treatment strategies. Thus, there is an urgent need for establishing efficient and innovative public policies concerning the handling and exploitation of wastes [2].

Waste disposal in sanitary landfills is the main waste management method in a majority of countries but requires large fields and results in several environmental issues. The new legislations within the European Union have led to setting out of operation many landfill areas, which in turn has resulted in a 25\% decrease of Municipal Solid Wastes (MSW) ending up in landfill facilities [3]. A promising alternative is the conversion of waste to energy. Waste-to-energy plants have gained a lot of interest lately; at present, the most mature technology is incineration, while gasification is still at an early development stage. Gasification is an advanced thermal treatment method and may attract more attention in the future, because it potentially presents smaller environmental burdens than incineration.

During gasification process organic materials are converted into a synthesis gas (syngas), a mixture containing mostly Hydrogen $\left(\mathrm{H}_{2}\right)$, Carbon monoxide $(\mathrm{CO})$ and Methane $\left(\mathrm{CH}_{4}\right)$ [4]. The syngas can then be utilized in advanced power technologies such as fuel cells for combined production of electricity and heat. Fuel cells are electrochemical devices that present higher efficiencies than most conventional power technologies. Solid Oxide Fuel Cells (SOFC) particularly, are capable of operating in high temperatures $\left(700-1,000{ }^{\circ} \mathrm{C}\right)$ and the resulted heat can then be used as a byproduct for Combined Heat and Power (CHP) applications. Furthermore, they present high fuel flexibility, since they can process $\mathrm{CO}$ and $\mathrm{CH}_{4}$ besides $\mathrm{H}_{2}$. The high fuel flexibility and the fact that the operating temperature range of gasification and SOFC is similar, makes coupling of the two technologies ideal [5].

Whereas CHP applications are well established and will continue growing in the upcoming years, research on tri-generation systems (CHCP) is more limited. The term CHCP generally implies the simultaneous production of heating, cooling and power by the same fuel input [6]. The cooling effect is usually produced through thermally driven refrigeration systems known as absorption chillers. The operating mode of $\mathrm{CHCP}$ systems depends on their application. For example, when installed in residential areas, they operate in CHP mode during the winter and the absorption chillers are only activated in the summer. On the other hand, the systems operate continuously in CHCP mode when implemented in buildings such as hospitals and hotels because of the continuous need for electricity, heating, and cooling. In general, the total efficiency of CHCP plants is much higher than conventional plants in which electricity, heating and cooling are produced separately. The explanation stems from the fact that in CHCP plants the same amount of fuel is consumed to cover all the demands, whereas more resources would be required in the second case [6].

Until now most of the studies related to $\mathrm{CHCP}$ systems refer to conventional prime movers. Denilson et al. [7] studied the performance of a CHCP plant based on internal combustion engine implemented in a hospital, by applying the following performance indicators: energy utilization factor, exergy efficiency and primary energy savings. Li et al. [8] analyzed a micro CHCP system based on internal combustion engine and a two bed silica gel-water adsorption chiller. Gas turbines as prime movers were utilized in the studies of $[9,10]$. Particularly in [9], a CHCP system based on a natural gas turbine working on full and part load conditions, and a vapor compression system for refrigeration purposes, was analyzed. Ziher et al. [10], conducted an economic study of a 
CHCP implemented in a Slovenian hospital. The system consisted of a natural gas turbine and the refrigeration load was covered either by vapor compression with cold storage, or absorption units. Schroeder et al. [11] studied the production of ice water from a CHCP, consisting of a steam turbine and an absorption unit operating on lithium bromide-water solution. 12. Poredos et al. [12] performed a comparison between steam and hot water driven absorption chillers, based on their exergetic efficiency. On the contrary, only few research has been conducted regarding the valorization of SOFCs as the prime movers in a CHCP system. Malico et al. [13] studied the design of a CHCP system based on natural gas fuelled SOFC coupled with an auxiliary boiler unit, in order to meet the energetic needs of a hospital. The system was found to be not financial feasible for different implemented scenarios. Weber et al. [14] investigated the Carbon dioxide $\left(\mathrm{CO}_{2}\right)$ emissions reduction potential and the resulted costs from the implementation of a CHCP system based on methane fuelled SOFC, in a building in Tokyo. They concluded that over $30 \% \mathrm{CO}_{2}$ reduction could be achieved at $70 \%$ cost increase compared to the conventional system. Moreover, Shaolin et al. [15] studied the coupling of SOFC based on methane and a gas turbine, together with an ammonia-water mixture introduced to recover the exhaust heat. The analysis resulted in conversion efficiency more than $80 \%$ under given conditions. The authors concluded that a thermo-economic analysis as well as an experimental study is further needed in order to validate the proposed system.

In most of the studies related to SOFC based CHCP, natural gas or pure methane is mainly used in the fuel cell anode, as described also above. Consequently, there is limited number of studies regarding the utilization of alternative fuels such as syngas resulted from MSW gasification, and are mainly related to co-generation systems. In particular, Rokni et al. [16] studied an integrated system of MSW, coupled with SOFC and a gas turbine. A second configuration was also analyzed, by implementing a hybrid recuperator after the compressor and before the cathode of the SOFC in order to recover more heat from the exhaust gases. The second configuration proved to be more efficient achieving a total system efficiency of $52 \%$ under optimal conditions. The same author performed a thermodynamic analysis of MSW gasification, integrated with SOFC and a Stirling engine as a bottoming cycle [17]. Hot water production available for space heating at $60{ }^{\circ} \mathrm{C}$ was also produced from the exhaust gases of the Stirling engine. The author conducted the analysis by using the mean value of seven different compositions of MSW, and for this value, $45 \%$ efficiency was achieved.

Therefore, a CHCP system based on SOFC that utilizes MSW as fuel constitutes a new area of research, a fact that creates the incentives for the investigation of potential benefits arising from such a configuration.

\section{SYSTEM OVERVIEW}

Figure 1 shows a complete overview of the proposed CHCP system. Dried MSW is supplied to the gasifier, where the syngas is produced through thermochemical reactions. The produced gas preheats air and steam needed for gasification and drying respectively, and then is cleaned from undesired contaminants such as sulfur and chlorine in hot gas cleaning reactors. Afterwards the cleaned gas enters the fuel cell cycle, where electricity and heat are generated. A burner is placed after the anode to ensure complete fuel conversion, and the resulting gases are cooled down to provide the heat needed for the absorption cycle. Finally, the rest of the waste heat contained in the exhaust gases is used for hot water production. The heat to the desorber is transferred through a closed water loop, assuring a better temperature match within both heat exchangers, which are connected in series. Moreover, since the heat transfer coefficient of water is higher than the exhaust gases, a smaller size of desorber can be achieved. 


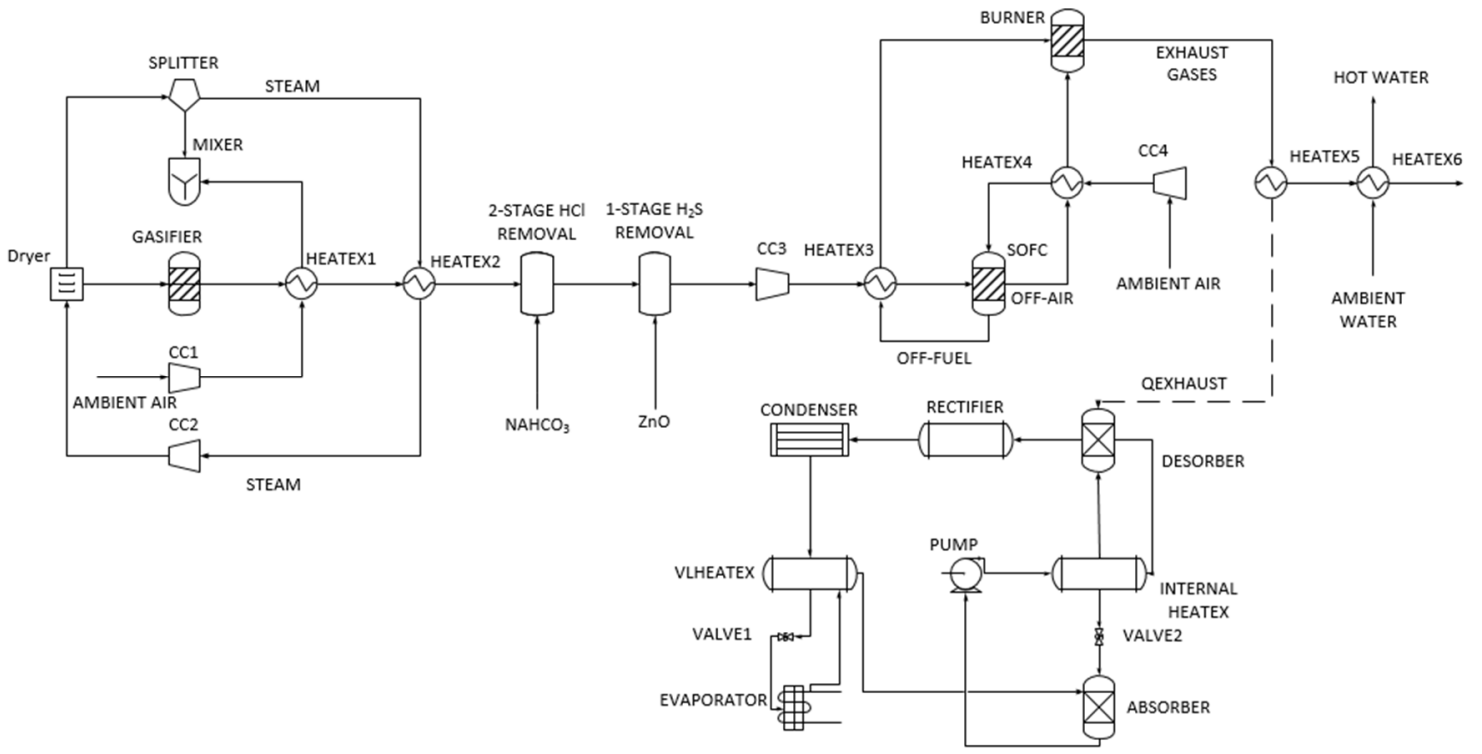

Figure 1. Complete overview of the CHCP system

\section{System efficiency}

The formula related to the calculation of the system efficiency is described in eq. (1). All the system's outputs are divided by the same magnitude which is the energy content of the initial fuel input on a Lower Heating Value (LHV) basis. In this way it is possible to identify how much energy contained in the MSW is transformed into electricity, heating and cooling and how much are the system losses. It is important to mention, that the formula below is introduced in a simplified manner and the reason is to estimate the overall performance of the plant. An exergy based approach is required in order to identify the location and the real magnitude of inefficiencies occurring in the plant, apart from the energy losses to the environment. However, an exergy analysis is out of the scope of the current work:

$$
n_{\text {System }}=\frac{\dot{P}_{\text {Net }}+\dot{Q}_{\text {Absorption }}+\dot{Q}_{\text {Heatex }}}{\dot{m}_{\mathrm{MSW}} L_{\text {MSW }}}
$$

$\dot{P}_{\text {Net }}$ is the net electrical power of the system and is calculated in eq. (2) by taking into account the gross electrical power $\dot{P}_{\text {Fuelcell }}$ and the power consumption of the four compressors. The power consumption of the pump is very small $(<2 \mathrm{~kW})$, consequently it is neglected. The terms $\dot{Q}_{\text {Absorption }}$ and $\dot{Q}_{\text {Heatex }}$ imply the cooling effect of the absorption cycle and the heat duty of heat exchanger (HEATEX6) assigned for the hot water production respectively:

$$
\dot{P}_{\mathrm{Net}}=\dot{P}_{\text {Fuelcell }}-\dot{W}_{\mathrm{CC} 1}-\dot{W}_{\mathrm{CC} 2}-\dot{W}_{\mathrm{CC} 3}-\dot{W}_{\mathrm{CC} 4}
$$

In order to determine the energy value of the waste delivered to a waste to energy plant, the energy content has to be calculated. There are two methods for determining the energy content:

- The Higher Heating Value (HHV);

- The Lower Heating Value (LHV).

The HHV relates to the complete combustion of a fuel from an initial state of $25^{\circ} \mathrm{C}$ and the return of the combustion products to the initial state. In this way the latent heat produced from the vaporization of the water contained in the fuel, is considered in the 
overall heating value. On the contrary, LHV refers to the complete combustion of a fuel from an initial state of $25^{\circ} \mathrm{C}$ and the return of the combustion products in the temperature of $150^{\circ} \mathrm{C}$ by cooling. The heat of water vaporization in this case is not taken into account. The calculation of these two values can be performed either by knowing the chemical analysis found by conducting experiments, either in the laboratory by using a bomb calorimeter. In the case of known chemical analysis, well known equations are introduced in order to calculate HHV and LHV respectively $[16,17]$. The elements in eq. (3) represent percentage by weight (ww\%) in the fuel on a dry basis:

$$
\begin{gathered}
\mathrm{HHV}=0.341 \mathrm{C}+1.322 \mathrm{H}_{2}-0.12\left(\mathrm{O}_{2}+\mathrm{N}_{2}\right)+0.0686 \mathrm{~S}-0.0153 \text { Ash }\left(\frac{\mathrm{MJ}}{\mathrm{kg}}\right) \\
\mathrm{LHV}=\operatorname{HHV}(1-\text { Moisture })-2.447 \text { Moisture }\left(\frac{\mathrm{MJ}}{\mathrm{kg}}\right)
\end{gathered}
$$

\section{Aspen Plus simulator}

The building of the complete CHCP model was developed in Aspen Plus simulator. Aspen Plus has been widely used for modelling complex steady-state processes in the fields of chemical and petrochemical engineering. It includes a large library of blocks such as compressors, heat exchangers and reactors that represent most operations in industrial processes. Furthermore, it constitutes of a large property databank containing information about thermo physical properties of different chemical substances and mixtures. The calculations related to the chemical reactors are performed based on the assumption of minimization of Gibbs free energy. It is assumed that the gas streams in the gasification and fuel cell sections have an ideal gas behavior (IDEAL property method). SOLID method was implemented regarding the modelling of sorbents in gas cleaning reactors. The fluid property package developed by REFPROP was used to model the absorption cycle system, as the working fluids are highly non-ideal mixtures for which reference equations of state are preferred over conventional ones.

\section{METHODS}

Gasification is a thermo-chemical process during which a carbonaceous feedstock is converted into a combustible gas by the supply of a gasification agent in a high-temperature environment [18]. It can also be described as a partial oxidation process, since the amount of oxygen is lower than the one needed for stoichiometric combustion [3].

Compared to the traditional method of incineration related to thermal waste treatment, gasification shows a number of significant advantages. Firstly, gasification is considered to be much cleaner technology regarding the level of emissions produced. More specifically in the incineration process, the combustion environment favors the formation of oxides of Sulfur $\left(\mathrm{SO}_{\mathrm{x}}\right)$, oxides of Nitrogen $\left(\mathrm{NO}_{\mathrm{x}}\right)$ and heavy metals which are considered to be major air pollutants. Furthermore, the ability of implementing gasification systems close to the waste source and to the end users saves significant costs regarding transportation and hauling of wastes, as well as it contributes to the promotion of decentralized heat and power production. Compared to the gas product of incineration technology, which can only be utilized in a boiler in order to produce steam destined to fuel a turbine, syngas on the contrary, can be utilized in various applications. Particularly, syngas can supply gas turbines, internal combustion engines, as well as fuel cells if it is totally pure, for the generation of heat and electricity. Furthermore it can be the base for the production of valuable chemicals, fuels and fertilizer products. 
The main reactions happening during the gasification stage are illustrated below. Eqs. (5-7) are known as oxidation or combustion reactions and they are highly exothermic, thus they provide the heat needed for the endothermic reactions happening inside the gasifier. Eq. (8) is the water-gas reaction; it is reversible and endothermic, meaning that a lot of energy is needed for its accomplishment. The operating conditions that favor this reaction are high temperatures and low pressures respectively. Eq. (9) is known as Boudouard reaction and contributes also to the gasification of carbon. If higher concentration of $\mathrm{CO}$ is desired, then the operating conditions favoring this specific reaction are high temperatures and low pressures. Eq. (10) represents the water-gas shift reaction where carbon monoxide reacts with steam in order to produce hydrogen and carbon dioxide. Based on the fact that hydrogen is characterized by higher energy content this reaction is highly aimed. During methanation reaction denoted in eq. (11) methane is produced. A higher methane concentration can be achieved in a low temperature and high pressure environment. Finally, eq. (12) relates to the steam reforming reaction of the produced methane, with hydrogen and carbon monoxide as products. It is highly endothermic and thus it is favored in higher temperatures:

$$
\begin{gathered}
\mathrm{C}+\frac{1}{2} \mathrm{O}_{2} \rightarrow \mathrm{CO} \text { with } \Delta \mathrm{H}^{\mathrm{O}}=-110.5 \frac{\mathrm{kJ}}{\mathrm{mol}} \\
\mathrm{C}+\mathrm{O}_{2} \rightarrow \mathrm{CO}_{2} \text { with } \Delta \mathrm{H}^{\mathrm{O}}=-398.8 \frac{\mathrm{kJ}}{\mathrm{mol}} \\
\mathrm{H}_{2}+\frac{1}{2} \mathrm{O}_{2} \rightarrow \mathrm{H}_{2} \mathrm{O} \text { with } \Delta \mathrm{H}^{\mathrm{O}}=-242 \frac{\mathrm{kJ}}{\mathrm{mol}} \\
\mathrm{C}+\mathrm{H}_{2} \mathrm{O} \leftrightarrow \mathrm{H}_{2}+\mathrm{CO} \text { with } \Delta \mathrm{H}^{\mathrm{O}}=131.3 \frac{\mathrm{kJ}}{\mathrm{mol}} \\
\mathrm{C}+\mathrm{CO}_{2} \leftrightarrow \mathrm{CO} \text { with } \Delta \mathrm{H}^{\mathrm{O}}=172.5 \frac{\mathrm{kJ}}{\mathrm{mol}} \\
\mathrm{CO}+\mathrm{H}_{2} \mathrm{O} \leftrightarrow \mathrm{H}_{2}+\mathrm{CO}_{2} \text { with } \Delta \mathrm{H}^{\mathrm{O}}=-41 \frac{\mathrm{kJ}}{\mathrm{mol}} \\
\mathrm{C}+2 \mathrm{H}_{2} \leftrightarrow \mathrm{CH}_{4} \text { with } \Delta \mathrm{H}^{\mathrm{O}}=-74.8 \frac{\mathrm{kJ}}{\mathrm{mol}} \\
\mathrm{CH}_{4}+\mathrm{H}_{2} \mathrm{O} \leftrightarrow 3 \mathrm{H}_{2}+\mathrm{CO} \text { with } \Delta \mathrm{H}^{\mathrm{O}}=206 \frac{\mathrm{kJ}}{\mathrm{mol}}
\end{gathered}
$$

\section{Gasification modelling}

Determination of the given input parameters to the system is based on the following assumptions. The gasifier is of the downdraft type, in isothermal, steady-state conditions and chemical reactions reach their equilibrium [18-21]. MSW at the ambient conditions ( $T=15^{\circ} \mathrm{C}$ and $p=1.013 \mathrm{bar}$ ), with a rate of $\dot{m}=130 \mathrm{~kg} / \mathrm{h}$ after drying and moisture content 10\% [22] enters a downdraft gasifier. The gasifier, where the decomposition of the fuel takes place followed by the combustion and gasification processes, operates at $800{ }^{\circ} \mathrm{C}$ and in atmospheric pressure. Ambient air is first compressed and then preheated before it is supplied into the gasifier. The produced syngas is then processed through the cleaning system, where Hydrogen chloride $(\mathrm{HCl})$ and Hydrogen sulfide $\left(\mathrm{H}_{2} \mathrm{~S}\right)$ are reduced to the desired ppm levels. 
The physical and chemical composition of MSW is derived from [23] and consists of $52 \%$ plastics, $10 \%$ textiles, $22 \%$ food waste and $16 \%$ paper. The volatile matter content was taken as an average value of the data found in [24] due to the lack of information. The author of [23] studied the chemical as well the physical composition of the waste produced in the National Hospital of Taiwan, thus it is considered representative for modelling hospital solid wastes. The chemical composition of waste is displayed in Table 1.

Table 1. Chemical composition of MSW

\begin{tabular}{ccc}
\hline Property & & Value \\
\hline Proximate analysis [ww\% dry basis] & Volatile matter & 83 \\
& Ash & 6.45 \\
& Fixed carbon & 10.55 \\
\hline Ultimate analysis [ww\% dry basis] & $\mathrm{C}$ & 54.09 \\
& $\mathrm{H}$ & 8.2 \\
& $\mathrm{O}$ & 24.12 \\
& $\mathrm{~S}$ & 0.04 \\
& $\mathrm{~N}$ & 1.3 \\
& $\mathrm{CL} 2$ & 4.3 \\
\hline Lower heating value dry basis $[\mathrm{kJ} / \mathrm{kg}]$ & & 15,600 \\
Moisture [\%] & & 38 \\
\hline
\end{tabular}

\section{Syngas cleaning}

Syngas produced through gasification contains different kinds of impurities such as particles, tars, sulfur, chlorine compounds and alkali metals, which can poison the catalysts used in the fuel cells. Pretreating the syngas is crucial to ensure high system performance and life expectancy [25]. The cleaning methods can be divided into two types, depending on their operating range: cold (below $200^{\circ} \mathrm{C}$ ) and hot (possibly above $500{ }^{\circ} \mathrm{C}$ ) gas cleaning [25]. Cold gas cleaning requires additional heating and cooling compared to hot gas cleaning, which results in an efficiency penalty and can generate waste streams that need further treatment. Hot gas cleaning may be more energy-efficient but is not a mature technology. Gas cleaning systems related to syngas produced from waste gasification are in general terms much simpler when compared to coal gasification. The feedstock supplied to the gasifier does not contain large particles, since they have been usually removed through recycling process, before the feedstock is fed to the gasifier. Alkali metals, such as potassium and sodium, are not present in the given MSW composition and consequently only the removal of $\mathrm{HCl}$ and $\mathrm{H}_{2} \mathrm{~S}$ compounds is taken into consideration. $\mathrm{HCl}$ can be removed in an absorption process by using calcium or sodium based sorbents, whereas metal oxides such as Zinc (Zn) and Molybdenum (Mo) can be used for the $\mathrm{H}_{2} \mathrm{~S}$ removal. Other particles can be removed in a high-temperature filter prior to $\mathrm{HCl}$ and $\mathrm{H}_{2} \mathrm{~S}$ catalysts. In this study the use of the sorbent Sodium bicarbonate $\left(\mathrm{NaHCO}_{3}\right)$ for $\mathrm{HCl}$ removal to few ppm level is determined, since it has proved to be very effective (99\% of $\mathrm{HCl}$ removal) within a temperature range of $350-500{ }^{\circ} \mathrm{C}$ [26]. Similarly, $\mathrm{H}_{2} \mathrm{~S}$, which is the most common sulfur-derived compound in the synthesis gas [26], is removed by absorption with commercially available sorbent Zinc oxide ( $\mathrm{ZnO})$ in temperatures between $350-450{ }^{\circ} \mathrm{C}$ [27-30].

\section{Fuel cells and Solid Oxide Fuel Cells modelling}

Fuel cells produce electricity directly from the fuel oxidation process, which can result in higher system performances. The electrical efficiencies range between 40 and 
$55 \%$, while the fuel utilization factor can reach up to $80 \%$ in CHP mode [17]. Meanwhile, the efficiency of internal combustion engines is approximately $30 \%$ and therefore, the introduction of fuel cell technologies in the power generation system can be highly beneficial. Fuel cells are characterized by low noise due to the lack of moving parts and very low emissions compared to other conventional technologies [5].

The calculation of the SOFC electrical output is based on the work of Zhang et al. [31]. The challenge of creating a SOFC model in Aspen Plus software lies on the fact that there is no model available in the software's component library. Thus, the author introduced an alternative method for the design of a tubular SOFC, by utilizing the existed building blocks of Aspen Plus. Afterwards, it was validated by performing a comparison to a Siemens-Westinghouse $100 \mathrm{~kW}$ class tubular SOFC stack.

The main input data is presented in Table 2. The electrical output results from an energy balance conducted in the anode reactor, taking into consideration the heat produced from the electrochemical reactions, the amount of air needed to keep the operating temperature of the cell stable, as well as an assumed percentage of $2 \%$ of heat losses. The SOFC operates in isothermal $\left(780{ }^{\circ} \mathrm{C}\right)$ steady-state atmospheric conditions. Syngas is compressed and preheated to $650{ }^{\circ} \mathrm{C}$ before entering the fuel cell on the anode side. The inlet gas composition (mol\%) is: $\mathrm{H}_{2} 34 \%, \mathrm{CO} 20 \%, \mathrm{CH}_{4} 0.04 \%$, Nitrogen $\left(\mathrm{N}_{2}\right)$ $27.14 \%, \mathrm{H}_{2} \mathrm{O} 11.3 \%, \mathrm{CO}_{2} 7.47 \%$. Similarly, the ambient air entering the SOFC is first compressed and preheated to $600{ }^{\circ} \mathrm{C}$. The flow leaving the SOFC on the anode side (off-fuel) still contains some unburnt fuel (depending on the fuel utilization factor $U_{F}$ ), which is burned in a catalytic burner where the depleted air (off-air from cathode), is also processed. The value of $U_{\mathrm{F}}$, set to 0.85 , is taken from $[31,32]$. The assumptions of the SOFC temperature inlets have been reported in [17]. Waste heat from the exhaust gases is used to drive the absorption plant as well as the hot water production. The off-gases after the burner are cooled to $150{ }^{\circ} \mathrm{C}$ in order to provide heat for the absorption cycle, while they are cooled to $100{ }^{\circ} \mathrm{C}$ for hot water production, thus avoiding acid gases condensation. The desired domestic hot water temperature is $55{ }^{\circ} \mathrm{C}$ and the isentropic efficiency of the compressors is $70 \%$.

Table 2. Input data to SOFC cycle

\begin{tabular}{cc}
\hline Parameter & Value \\
\hline Operating temperature in SOFC $\left[{ }^{\circ} \mathrm{C}\right]$ & 780 \\
Operating pressure in SOFC $[$ bar $]$ & 1.17 \\
Utilisation factor $\left(U_{\mathrm{F}}\right)[-]$ & 0.85 \\
Fuel inlet temperature $\left[{ }^{\circ} \mathrm{C}\right]$ & 650 \\
Air inlet temperature to SOFC $\left[{ }^{\circ} \mathrm{C}\right]$ & 600 \\
Mass flow of air $[\mathrm{kg} / \mathrm{sec}]$ & 1.04 \\
Cooling temperature of burner's exhausts $\left[{ }^{\circ} \mathrm{C}\right]$ & 150 \\
\hline
\end{tabular}

\section{Absorption chillers and modelling of single stage ammonia-water cycle}

Refrigeration systems based on vapour absorption cycles are a well-known technology, but their market share is still limited compared to the vapour compression systems, because of their low efficiency and high capital costs. Typical values of the Coefficient of Performance (COP) for absorption cycles range between 0.5 and 1.5, while they exceed 3 in the case of vapour compression cycles [33]. Albeit their disadvantages, the utilization of absorption cycles is significantly favoured when waste heat is available, especially if hot exhaust gases resulting from industrial processes are directly discharged in the surroundings. The integration of absorption chillers which utilize this heat that otherwise would be wasted, can lead to an increase in the overall plant efficiency. 
An ammonia-water rich solution consisting of $60 \% \mathrm{H}_{2} \mathrm{O}$ and $40 \%$ Ammonia $\left(\mathrm{NH}_{3}\right)$ on a molar basis, is pumped to the desorber after internal heat recovery with the hot weak solution (poor concentration of ammonia). Heat from the burner exhausts is introduced to the desorber resulting in partial evaporation of ammonia and water. In the outlet of the desorber the mixture generally contains about $5-10 \%$ water on a mass basis, thus further decrease in the water concentration is needed. This is achieved through cooling and condensation in the rectifier. As a result, almost pure ammonia mixture is led to the condenser where it is transformed into a liquid solution. A Vapor-Liquid Heat Exchanger (VLHEATEX) is implemented afterwards in order to sub cool the mixture, which then enters in an expansion valve where its pressure is decreased to the low pressure level of the cycle. The weak ammonia-water solution exiting the desorber is mixed with the water removed in the rectifier. It is then expanded and mixed with ammonia exiting the vapor-liquid heat exchanger in the absorber, thus closing the cycle. The rectifier temperature, as shown in Table 3 , is set to $95^{\circ} \mathrm{C}$ in order to achieve an ammonia purity of $98 \%$ in the gas phase at the outlet. The mass flow of the solution is adjusted to achieve the desired temperature of $105{ }^{\circ} \mathrm{C}$ in the desorber, based on the waste heat available of $266 \mathrm{~kW}$. The evaporator and condenser temperatures are deduced from the constraint related to the assumed minimum temperature difference of $5 \mathrm{~K}$ in the heat exchangers.

The assumptions needed for a realistic modelling of the absorption cycle are as follows:

- Saturated liquid conditions in the outlet of the absorber and the condenser;

- The cooling medium in the evaporator is air which is cooled from $25{ }^{\circ} \mathrm{C}$ to $22.5^{\circ} \mathrm{C}$, based on the environmental conditions for thermal comfort [34];

- Water in initial temperature of $15^{\circ} \mathrm{C}$ is used as a cooling medium in the absorber, rectifier and condenser.

Table 3. Input conditions of the absorption cycle

\begin{tabular}{cc}
\hline Parameter & Value \\
\hline Condenser temperature $\left[{ }^{\circ} \mathrm{C}\right]$ & 35 \\
Evaporator temperature $\left[{ }^{\circ} \mathrm{C}\right]$ & 17.5 \\
Rich solution $[\mathrm{kg} / \mathrm{sec}]$ & 1.78 \\
Desorber temperature $\left[{ }^{\circ} \mathrm{C}\right]$ & 105 \\
Rectifier temperature $\left[{ }^{\circ} \mathrm{C}\right]$ & 95 \\
Heat input to the desorber $[\mathrm{kW}]$ & 266 \\
Pressure condenser $[\mathrm{bar}]$ & 13.23 \\
Pressure evaporator $[\mathrm{bar}]$ & 2.01 \\
\hline
\end{tabular}

\section{Sensitivity analysis}

A sensitivity analysis needs to be performed in order to identify the impact of varying parameters on the system efficiency. The parameters to be varied are the Air Equivalent Ratio (AER) and the operating temperatures of the gasifier and desorber respectively.

\section{Techno-economic analysis}

Apart from the thermodynamic analysis of the studied system, a techno-economic analysis is also performed to investigate the cost effectiveness of the plant. The data related to the Purchased Equipment Cost (PEC) stems from [35-38]. The unit cost is in (USD_2015). The cost estimation of SOFC, which is not yet in the market, builds on the following considerations. The cost of SOFC is calculated from eq. (14) based on the study of [40] which was derived for serial cell production in a future scenario. It should be noted that such hypothesis may change in the future and the authors use this relation since no other relation can be found in the open literature. At present, the cost is four 
times larger due to non-commercialization. Regarding the purchased cost of the gasifier, a number of fixed-bed applications have been recorded around the world and cost estimates are available in the literature. Absorption technology is a mature technology and the related cost data is readily available as well.

In eqs. (13-16) the cost correlations related to gasifier, SOFC, absorption chiller and counter flow heat exchanger respectively, are presented. In eq. (13) $\dot{m}_{\mathrm{MSW}}$ refers to the mass flow $(\mathrm{kg} / \mathrm{sec})$ of dried MSW entering the gasifier reactor. The terms $N_{\text {Cells }}$ and $D_{\text {Cells }}$ in eq. (14) relate to the number of cells within a stack as well the diameter of each cell in (m). The cost factor $F_{\mathrm{AC}}$ in eq. (15) depends on the heat source as well as from the chiller's single or double effect. For a single effect absorption chiller and water as the heat source which is the case of the specific study, the cost factor is determined to be 1. The term $A_{\text {Heatex }}$ refers to the heat transfer area, which is calculated in eq. (17). $Q$ is the heat exchanger duty in (W), LMTD is the mean logarithmic temperature difference in every heat exchanger and $U\left(\mathrm{~W} / \mathrm{m}^{2} \mathrm{~K}\right)$ is the overall heat transfer coefficient. The values of $U$ depend on the working fluids and the considered values are taken from literature. Finally the correlations related to other components of the plant such as compressors, pumps are well known, thus there is no need of mentioning them and can be found in the references stated above:

$$
\begin{gathered}
C_{\text {Gasifier }}=2.9 \times 10^{5}\left(3.6 \dot{m}_{\mathrm{MSW}}\right)^{0.7} \\
C_{\text {Stack,SOFC }}=\left(N_{\text {Cells }} \pi D_{\text {Cells }} L_{\text {Cells }}\right)\left(2.69 T_{\mathrm{SOFC}}-1,907\right) \\
C_{\text {Absorption }}=F_{\mathrm{AC}} 4 \times 10^{4}\left(\frac{\dot{Q}_{\text {Absorption }}}{70}\right)^{0.543} \\
C_{\text {Heatex }}=130\left(\frac{A_{\text {Heatex }}}{0.093}\right)^{0.78}
\end{gathered}
$$

where:

$$
A_{\text {Heatex }}=\frac{\dot{Q}_{\text {Heatex }}}{U_{\text {LMTD }}}
$$

The costing method, for the calculation of the Total Capital Investment (TCI) is described thoroughly in [39] and presented in Figure 2. The TCI is the sum of Fixed Capital Investment (FCI) and other outlays which are referring to the start-up costs and the licensing of a project as well as to the working capital. Working capital relates not only to the payment of salaries but also to the expenses associated with materials, fuels and different kinds of prerequisites regarding the operation. FCI is the sum of Total Direct Costs (TDC) and Total Indirect Costs (TIC), respectively. TDC are further divided in onsite and offsite costs. The former costs are associated with the Purchased cost of Each Component (PEC), the installation costs and the equipment needed for system controlling. The latter costs refer to service facilities such as water and electricity utilities and the civil and architectural work. Finally TIC relates to the oversight of the system, the arrangement of any uncertainties or risks that will arise during the project and the costs that are destined for the contractor's payment.

The calculation of the Annual Investment (ACI) is essential to understand the different capital costs involved in the installation and maintenance of the plant. First, the operating time of the plant is considered to be 20 years. The maintenance factor ( $\left.f_{\text {Maintenance }}\right)$ refers to the deterioration of the equipment along the operating years and the consequent adding costs that arise for service and maintenance. The chosen value is $1.1 \%$ and has been retrieved from [37]. The factor of discount rate ( $\left.f_{\text {Discount }}\right)$ has to do with the 
costs that stem from the fact that the money for the construction of the plant shall be borrowed. Even if the money is supplied from internal sources, there is still an opportunity cost, since the money could be utilized elsewhere or even deposited in to a bank [40]. The value of 5\% is selected from [41] and refers to a socio-economic perspective. The inflation factor, which is the price level changing rate over the years, is taken to a typical value of $2 \%$. Finally, the last two factors, $f_{\text {Insurance }}$ and $f_{\text {Taxation }}$ are related to the impacts of taxation and insurance elements on the annual investment. The corresponding values of $0.2 \%$ and $0.54 \%$ have been reported in [40].

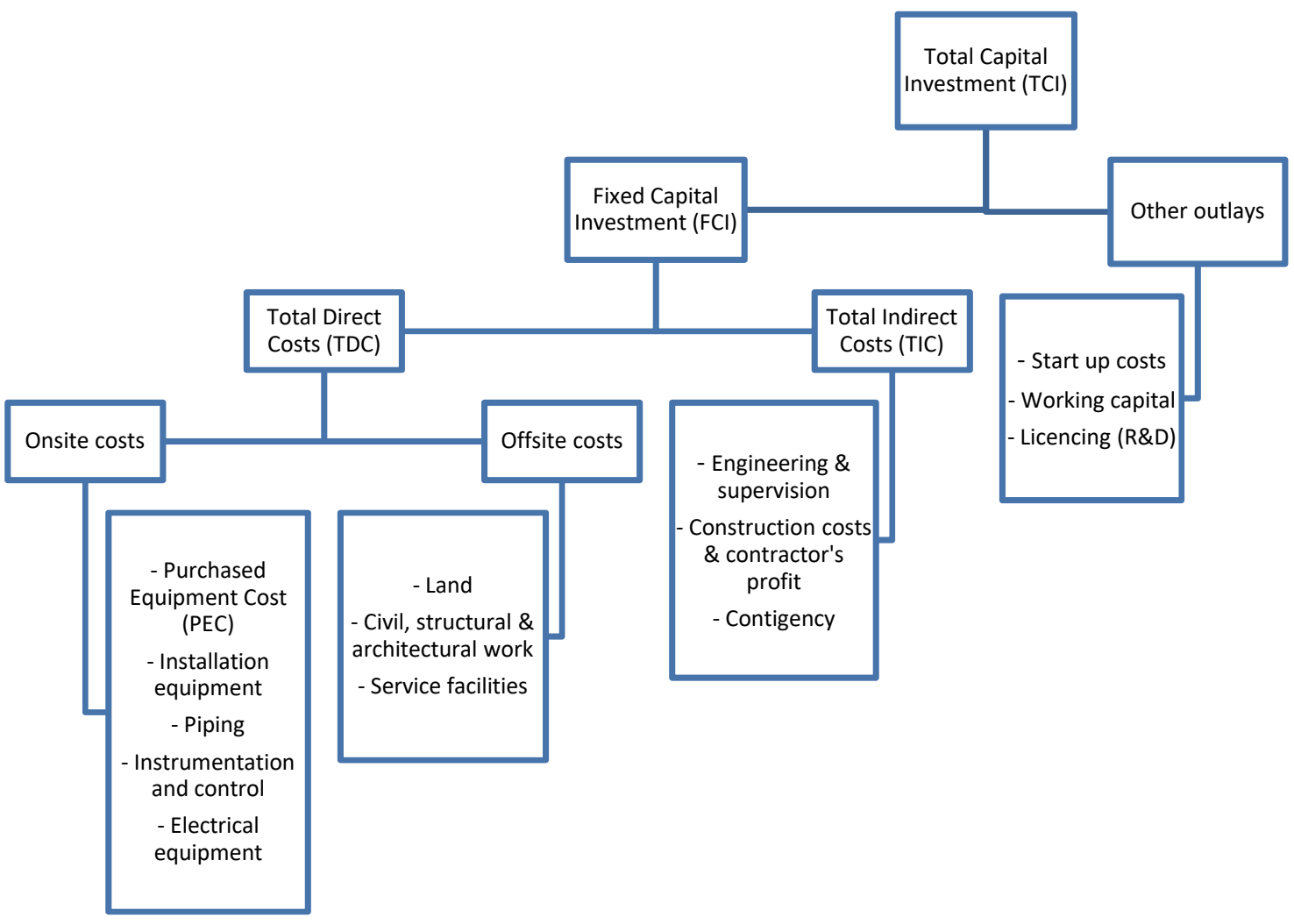

Figure 2. Overview of TCI calculation

Eqs. (18-22) describe the formulas for the calculation of different costs based on the factors explained above:

$$
\begin{gathered}
C_{\text {Depreciation }}=\frac{\mathrm{TCI}}{n} \\
C_{\text {Maintenance }}=\frac{\mathrm{TCI}}{n} f_{\text {Maintenance }} \\
C_{\text {Discount }}=\frac{\mathrm{TCI}}{n} f_{\text {Discount }} \\
C_{\text {Taxation }}=\frac{\mathrm{TCI}}{n} f_{\text {Taxation }} \\
C_{\text {Insurance }}=\frac{\mathrm{TCI}}{n} f_{\text {Insurance }}
\end{gathered}
$$


The annual capital investment $\left(C_{\mathrm{ACI}}\right)$ is simply the sum of the different costs as presented in eqs. (8-16):

$$
C_{\mathrm{ACI}}=C_{\text {Depreciation }}+C_{\text {Maintenance }}+C_{\text {Discount }}+C_{\text {Taxation }}+C_{\text {Insurance }}
$$

\section{RESULTS AND DISCUSSION}

The net electrical output of the system is $376 \mathrm{~kW}$, calculated as described in eq. (2). Furthermore, cooling effect created in the absorption system amounts $154 \mathrm{~kW}$, while the heat duty in HEATEX6 results in $60 \mathrm{~kW}$. The initial energy input to the system, which is the product of the mass flow $(\mathrm{kg} / \mathrm{sec})$ and LHV $(\mathrm{kJ} / \mathrm{kg})$ of MSW is $810 \mathrm{~kW}$. Thus, according to eq. (1) the system efficiency is approximately $73 \%$. A summary of the results is given in Table 4. The removal of $\mathrm{HCl}$ is accomplished in a two-stage cleaning process. The mass flow rate of sorbent $\mathrm{NaHCO}_{3}$ is $0.0034 \mathrm{~kg} / \mathrm{sec}$ and the temperature within the reactor is assumed to be $450{ }^{\circ} \mathrm{C}$, in atmospheric pressure. Regarding the removal of $\mathrm{H}_{2} \mathrm{~S}$ one stage cleaning reactor is implemented in the same operating conditions. The mass flow of $\mathrm{ZnO}$ sorbent is set to $5 \times 10^{-5} \mathrm{~kg} / \mathrm{sec}$. Both compounds are reduced down to less than 1-ppm levels.

Table 4. Efficiency and system outputs

\begin{tabular}{cc}
\hline System output & Value \\
\hline$\dot{P}_{\text {Net }}[\mathrm{kW}]$ & 376 \\
$\dot{Q}_{\text {Absorption }}[\mathrm{kW}]$ & 154 \\
$\dot{Q}_{\text {Heatex }}[\mathrm{kW}]$ & 60 \\
$n_{\text {System }}[\%]$ & 73 \\
\hline
\end{tabular}

\section{Effect of gasification temperature}

The operating temperature inside the gasifier is a very crucial parameter regarding the gasification process since it greatly affects the syngas composition. In Figure 3 the trends of the different chemical elements are illustrated while varying the gasifier temperature in the range of $650-950{ }^{\circ} \mathrm{C}$. It can be observed that the $\mathrm{H}_{2}$ content increases slightly from $650{ }^{\circ} \mathrm{C}$ to $700{ }^{\circ} \mathrm{C}$, where it starts to decline. $\mathrm{CO}$ shows a significant increase from $22.5 \%$ to $32.5 \%$ (40\% increase), while $\mathrm{CO}_{2}$ follows the opposite trend with a $45 \%$ decrease (from $22 \%$ to $12 \%$ ). The $\mathrm{CH}_{4}$ content decreases with an increasing temperature, while the water fraction rises from $700{ }^{\circ} \mathrm{C}$ and forward (24\% increase). The diverse trends in the syngas composition can be explained by the thermochemical reactions occurring inside the gasifier. The increase in the gasification temperature favors the products of the endothermic reactions, meaning that the hydrogen content increases due to water-gas and steam reforming reactions. The small reduction of the produced hydrogen, from the temperature of $700{ }^{\circ} \mathrm{C}$ and so forth, results from the lack of methane. The same reactions that favor the production of $\mathrm{H}_{2}$, are responsible for the $\mathrm{CO}$ increase, together with the Boudouard reaction. The constant decrease of the methane content results from the predominance of the steam reforming reaction at higher temperatures. Furthermore, the decrease of $\mathrm{CO}_{2}$ can be attributed to the facilitation of Boudouard reaction in the expense of the combustion reaction of carbon. Finally, steam is consumed in the water-gas, water-gas-shift and steam reforming reactions. After the temperature of $650{ }^{\circ} \mathrm{C}$, the flow of $\mathrm{CH}_{4}$ decreases dramatically, limiting the steam reforming reaction. Furthermore, the increase in gasifier temperature impedes the water-gas-shift reaction, as it is mildly exothermic. These two aspects explain the upward trend of $\mathrm{H}_{2} \mathrm{O}$. In general, higher operating temperatures of the gasifier are more preferable since syngas with high heating values is produced. On the other hand, too high temperatures can cause ash agglomeration inside the gasifier. 


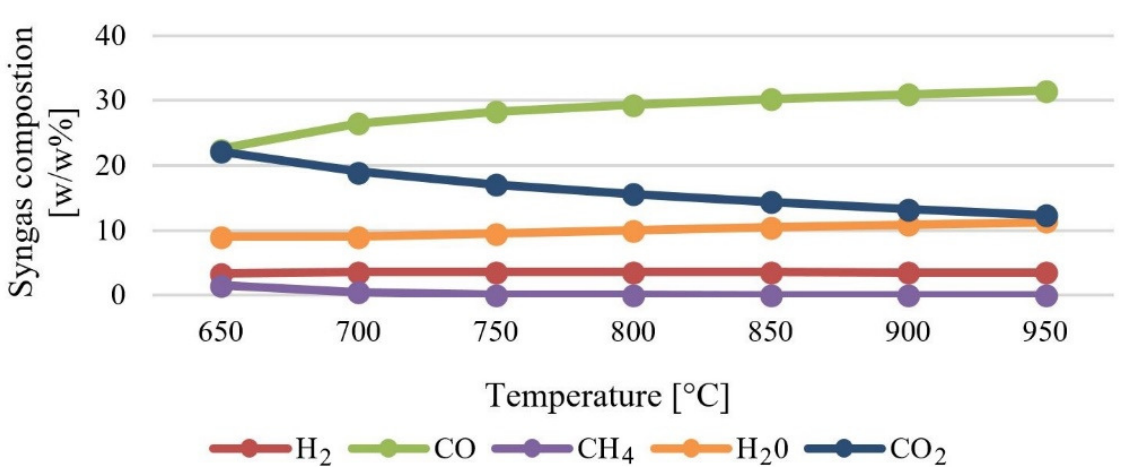

Figure 3. Effect of gasification temperature on syngas composition

\section{Effect of Air Equivalent Ratio}

The term AER is coined for the ratio between the air which is introduced in the gasifier and the necessary amount of air to achieve stoichiometric combustion. In Figure 4a the effect of AER on the syngas composition is illustrated. CO shows a large decrease of $79 \%$ (from $29.4 \%$ to $6.2 \%$ ), while $\mathrm{CO}_{2}$ rises from $15.6 \%$ to $20 \%$ (28\% increase) as the AER varies from 0.2 to 0.6. The trends of $\mathrm{CO}$ and $\mathrm{CO}_{2}$ can be attributed to combustion reactions. In practice, larger values of AER mean higher amounts of oxygen inside the gasifier, something that favors the combustion reactions. Complete carbon combustion is favored over partial combustion because of the higher oxygen concentration, which explains the increase of $\mathrm{CO}_{2}$ and the decrease of $\mathrm{CO} . \mathrm{H}_{2}$ also decreases from $3.6 \%$ to $0.8 \%$ ( $78 \%$ decrease), whereas $\mathrm{H}_{2} \mathrm{O}$ increases by $32 \%$ (from $10 \%$ to $13.3 \%$ ). The downward trend of $\mathrm{H}_{2}$ can be ascribed again to the dominance of combustion reaction of hydrogen, which causes also the rise of $\mathrm{H}_{2} \mathrm{O}$ fraction as the AER increases. The percentage of methane is also lowered but its percentage is very low and thus it is not possible to show it in Figure 4a. In Figure 4b the impact on the system's outputs when varying the AER is depicted: an increase in AER has a negative effect on the system efficiency. Particularly, net power production decreases in higher AERs. The same applies to the cooling effect, since less heat is transferred to the absorption system from cooling the exhaust gases exiting the burner. Heat duty in HEATEX6 depicts a constant trend since the same mass flow of exhaust gases enter the heat exchanger where the ambient water is heated up to $55^{\circ} \mathrm{C}$. System efficiency drops from $73 \%$ to $38 \%$ with an increase of the AER from 0.2 to 0.6 . In general terms, the AER should be as low as possible to avoid the complete combustion of fuel, while ensuring in the same time complete conversion of carbon.
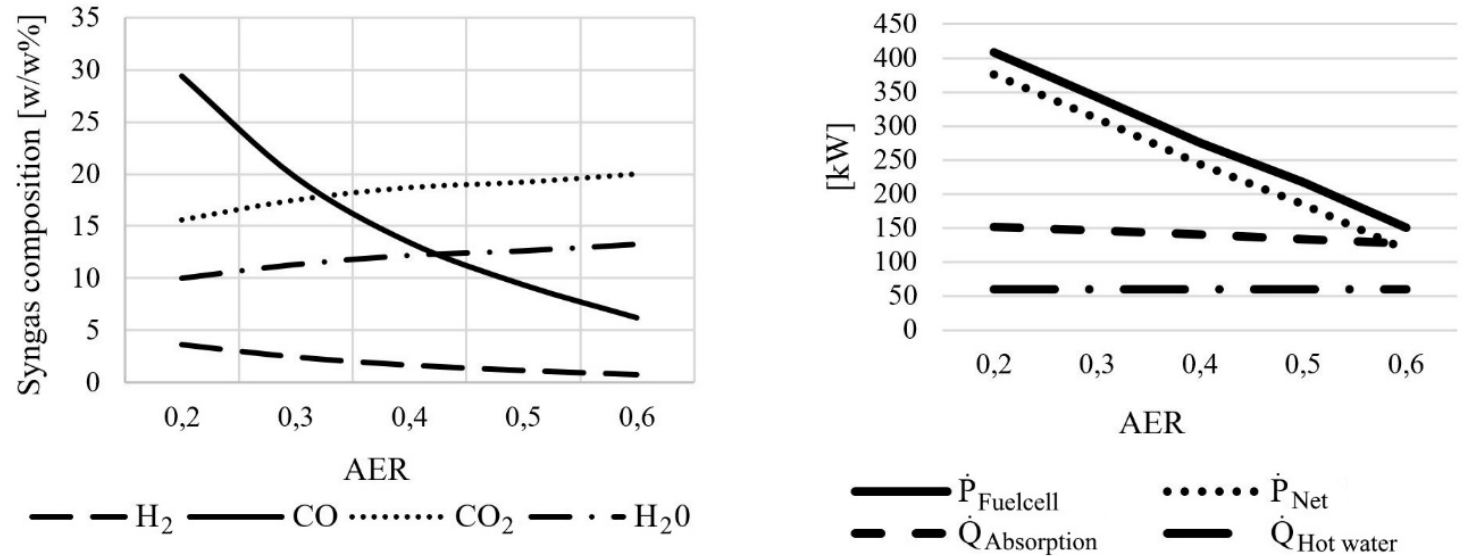

Figure 4. Syngas composition versus AER (a); electrical, heating and cooling outputs versus AER (b) 


\section{Effect of desorber temperature}

In Figure 5 the effect of varying the desorber temperature on the cooling effect created in the evaporator, as well as on system efficiency, is presented. Since the changes made will only affect the absorption cycle, it is needless to show net electrical output and heating duty which shall remain stable. The optimal cooling output and thus the highest system efficiency is pointed at the temperature of $105^{\circ} \mathrm{C}, 154 \mathrm{~kW}$ and $73 \%$, respectively.

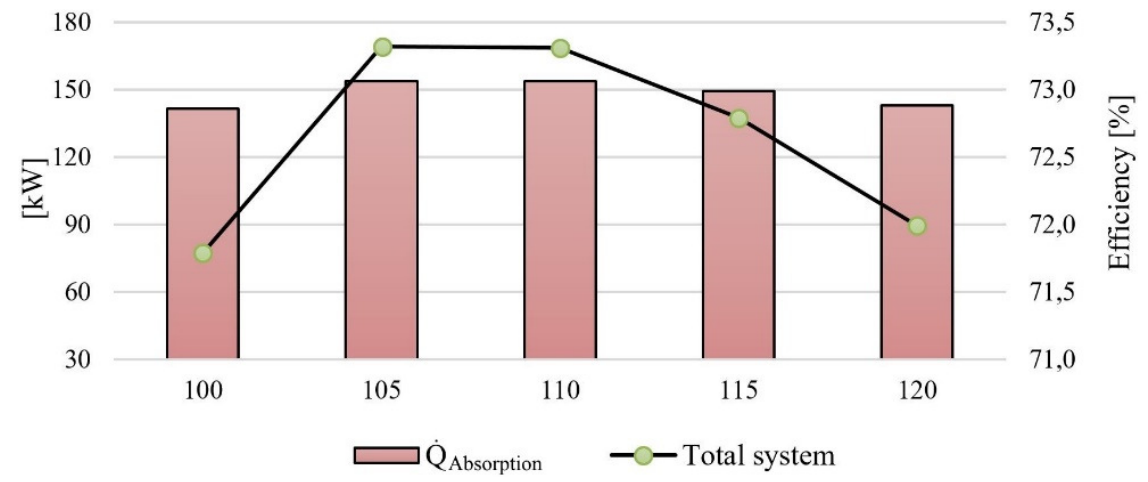

Figure 5. Cooling output and total system efficiency versus desorber temperature

In general terms, higher desorber temperatures lead to lower ammonia concentrations because of water evaporation, although more ammonia goes to the gas phase, leading to a lower cooling effect. This trade-off between the higher ammonia flow rate and lower concentration in the solution results into the peak of the absorption cooling effect observed at $105^{\circ} \mathrm{C}$.

\section{Cost of the system}

The TCI of the complete system amounts to about USD 2,326,000. The PEC is USD 540,200 while the ACI, based on eq. (23), is 81,400 USD/year. The fuel cost, which is, in this case, municipal solid waste, is taken to be zero. In Table 5 the purchased costs of the most expensive components are illustrated.

Table 5. Purchased costs of the most expensive components

\begin{tabular}{cc}
\hline Component & Value [USD] \\
\hline SOFC & 300,000 \\
Downdraft gasifier & 69,378 \\
Absorption unit & 61,376 \\
HEATEX 4 & 29,658 \\
HEATEX 6 & 15,503 \\
$\mathrm{H}_{2} \mathrm{~S}$ removal reactor & 7,800 \\
$\mathrm{HCl} \mathrm{removal} \mathrm{reactor}$ & 7,760 \\
CC 4 & 7,200 \\
\hline
\end{tabular}

\section{FEASIBILITY STUDY}

$\mathrm{CHCP}$ systems are well-suited for buildings where there is simultaneous need for electricity, heating and cooling demand. The aim of the present case study is to investigate the potential benefits of implementing the studied system and also the economic feasibility of the project. More specifically, a demand profile of a selected building has been derived from [41] and is shown in Figure 6. As it is observed, the 
electricity demand has an approximate stable profile during January-March and October-December, whereas it displays a significant decrease from June to September. The cooling demand exists only for five months, from May to September, while the heating demand is present throughout all the year with fluctuations.

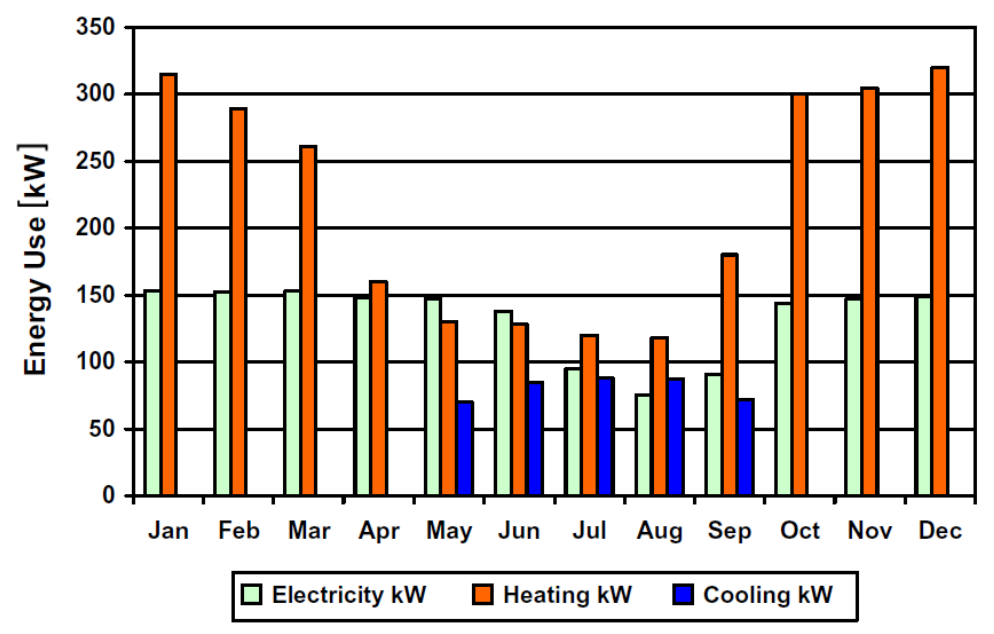

Figure 6. Demand profiles of the chosen building [42]

The consumption of MSW is adjusted to cover the peak electricity demand, and a natural gas boiler is used to cover the remaining heating demand, if existent. The cooling effect is covered by the ammonia vapor compression cycle. The electricity needed to run the refrigeration cycle is not included in the electricity profile of Figure 6. The prices of natural gas and electricity are assumed to be $0.068 \mathrm{EUR} / \mathrm{kWh}$ and $0.203 \mathrm{EUR} / \mathrm{kWh}$, respectively. They are extracted from [43], by taking the average prices in European Union (EU-27) for the year 2014, accounting for households-services. It is assumed that this system has a lifetime of 20 years for an annual operation of 8,760 hours. The dollar-to-euro conversion factor is taken to be 0.9 EUR/USD.

The initial mass flow of MSW is adjusted to $90 \mathrm{~kg} /$ hour before drying, which corresponds to a net electric power capable of satisfying the peak demand of $150 \mathrm{~kW}$ observed in Figure 6. The energy required to drive the compressor of the vapor compression cycle was performed in software COOLPACK, by giving as inputs the same condensation and evaporation temperatures considered in the absorption system modelling above and ammonia as the refrigerant. The ideal COP for the desired temperature lift is 16.6 , while the required compression work is $7.2 \mathrm{~kW}$, for a cooling effect of $72 \mathrm{~kW}$ [eq. (24)]. The Carnot efficiency is calculated in eq. (25) and is in agreement with the values described in [44]:

$$
\begin{gathered}
\mathrm{COP}_{\text {Real }}=\frac{\text { Cooling effect }}{\dot{W}}=10 \\
\eta_{\text {Carnot }}=\frac{\mathrm{COP}_{\text {Real }}}{\mathrm{COP}_{\text {Ideal }}}=0.6
\end{gathered}
$$

It is important to mention here that the values of demand profiles taken into account, relate to the average values throughout the year $(135 \mathrm{~kW}$ for the electricity, $220 \mathrm{~kW}$ for heating and $72 \mathrm{~kW}$ for cooling). The system runs in co-generation mode during the months when cooling demand does not exist. The change in mode is made by bypassing HEATEX5, which corresponds to the heat transfer to the desorber. An interesting aspect is that the system shows higher efficiency when operating in CHP mode instead of CHCP 
mode. This results from the fact that more heat is produced in CHP compared to the sum of heating and cooling outputs in the CHCP mode. The system efficiency in CHCP mode amounts $75 \%$, while the respective one of CHP mode results in $94 \%$.

\section{Energy savings}

Regarding the energy savings if the system is to be implemented, it is observed the electricity and cooling demand of the building are fully covered. Excess electricity can be sold to the grid, but, since the case study focuses primarily on the energy savings, no further research will be conducted regarding the electricity market. The heating demand is covered up to $55 \%$ and the rest is supplied by a natural gas boiler. The average heat demand is $1,927,200 \mathrm{kWh}$, while the heat produced from the system is 1,061,856 $\mathrm{kWh}$. The annual cost of natural gas needed in the boiler amounts 43,267 EUR/year.

The Payback Period (PBP) and Net Present Value (NPV) in Table 6 are calculated in order to investigate the economic feasibility of this system. The former indicator is a simple form of financial analysis, which takes into account the capital cost of the investment and compares it with the annual revenues that the system would create. The latter indicator allows the future value of cash flows to be adjusted to a reference year by applying an interest rate. The TCI reaches about 1,358,770 EUR, while the PBP is 4.5 years. The earnings from the energy savings are approximately 5 M EUR, based on the NPV for the system lifetime.

Table 6. Energy savings and PBP

\begin{tabular}{c|c}
\hline Average electricity usage [kWh/year] & $1,208,520$ \\
Average heat usage [kWh/year] & $1,927,200$ \\
Average cooling usage [kWh/year] & 259,200 \\
Annual electricity cost [EUR/year] & 241,704 \\
Annual natural gas cost [EUR/year] & 96,360 \\
Total energy bill [EUR/year] & 338,064 \\
Average electricity generated [kWh/year] & $1,314,000$ \\
Electricity purchased from the grid [EUR] & 0 \\
Annual cost of electricity purchased [EUR] & 0 \\
Average heat generated [kWh/year] & $1,061,856$ \\
Heat produced from natural gas boiler [kWh/year] & 865,344 \\
Annual cost of purchased natural gas [kWh/year] & 43,267 \\
Average cooling generated (kWh) [kWh/year] & 259,200 \\
Cooling produced from vapor compression chillers [kWh/year] & 0 \\
Annual cost of electricity [EUR/year] & 0 \\
Annual energy bill (system implementation) [EUR/year] & 43,267 \\
Annual energy savings [EUR/year] & 294,797 \\
System capital cost [EUR] & $1,513,000$ \\
PBP (years) & 4.5 \\
NPV [M EUR] & $\sim 5$ \\
\hline
\end{tabular}

\section{CONCLUSIONS}

The objective of the present study is to investigate the performance of a novel CHCP system based on MSW gasification coupled with a SOFC and an ammonia-water absorption chiller. CHCP systems are a considerable option when implemented in buildings such as hospitals, hotels and airports, where there is a continuous and large demand for electricity, heating and cooling. Different parameters were varied to 
investigate their impact on the system efficiency. The AER is shown to be a very important parameter regarding the gasification process, since it greatly influences the heating value of the fuel, which decreases sharply with higher AERs, resulting in lower system efficiencies. Moreover, higher gasification temperatures favor the production of a syngas characterized by larger energy contents. Hot gas cleaning method by the injection of sorbents $\mathrm{ZnO}$ and $\mathrm{NaHCO}_{3}$ displayed very good performance, as the concentrations of $\mathrm{H}_{2} \mathrm{~S}$ and $\mathrm{HCl}$ in the syngas are decreased below 1-ppm levels prior to the SOFC. An investigation of whether it is feasible to implement the system on a selected building was also conducted. Since it was not possible to acquire the energy demand data from the same hospital that the waste composition was taken into consideration, a demand profile from a building found in literature was selected. The techno-economic analysis showed that the system could successfully cover the electrical and cooling demands, whereas the heat demand was satisfied to a percentage of 55\%. The remaining part was covered by natural gas boilers. The payback period was approximately 4.5 years.

Since the system is quite novel, there are challenges for all the technologies to be addressed. A significant challenge to tackle is the selection of a suitable type of gasifier, which would be appropriate for highly diverse feedstock compositions. The MSW composition can be different from one place to another since it is dependent on various parameters, such as the consumer's habits and income. Pretreatment and sorting of MSW before gasification is necessary to ensure an efficient operation, which may, in turn, result in higher costs. Moving on to fuel cells technology, the most important burden for penetrating the power market is their significant capital costs, estimated to 3,000 EUR/kW at present. If fuel cells shall compete with other power production technologies for stationary applications, the cost must be reduced within the range of 750-1,500 EUR/ $\mathrm{kW}$. In contrast to gasification and fuel cells, absorption cooling is a more mature technology, which is, however, on the sideline of the cooling market due to the high prevalence of conventional vapor compression cycles. The most commercial combinations of operating fluids, water-lithium bromide and ammonia-water, suffer from crystallization and corrosion issues, and the values related to COP compared to vapor compression cycles are relatively low. As a result, absorption cycles are usually preferred when waste heat is available, since it does not result in additional costs, but, on the opposite, can contribute to the reduction of electricity costs.

\section{NOMENCLATURE}

$A_{\text {Heatex }}$
$C_{\text {Absorption }}$
$C_{\text {ACI }}$
$C_{\text {Depreciation }}$
$C_{\text {Discount }}$
$C_{\text {Gasifier }}$
$C_{\text {Insurance }}$
$C_{\text {Maintenance }}$
$C_{\text {Stack,SOFC }}$
$C_{\text {Taxation }}$
$D_{\text {Cells }}$
$F_{\text {AC }}$
$f_{\text {Discount }}$
$f_{\text {Insurance }}$
$f_{\text {Maintenance }}$
$f_{\text {Taxation }}$
$L$ Cells

heat transfer area

$\left[\mathrm{m}^{2}\right]$

cost of chiller

[USD]

annual cost

[USD]

depreciation cost

[USD]

discount rate cost

[USD]

gasifier cost

[USD]

insurance cost

[USD]

maintenance cost

[USD]

cost of SOFC stack

[USD]

taxation cost

[USD]

cell diameter

[m]

cost factor

[-]

discount factor

[-]

insurance factor

[-]

maintenance factor

$[-]$

taxation factor

[-]

cell length

[m] 


$\dot{m}_{\mathrm{MSW}}$
$p$
$\dot{P}_{\text {Fuelcell }}$
$\dot{P}_{\text {Net }}$
$\dot{Q}_{\text {Absorption }}$
$\dot{Q}_{\text {Heatex }}$
$T$
$U$
$U_{\mathrm{F}}$
$\dot{W}_{\mathrm{CC}}$

\section{Greek letters}

$\eta_{\text {Carnot }}$

mass flow
pressure
gross power of fuel cell
net power of fuel cell
cooling duty
heat exchanger duty
temperature
heat transfer coefficient
fuel utilisation factor
work of compressor

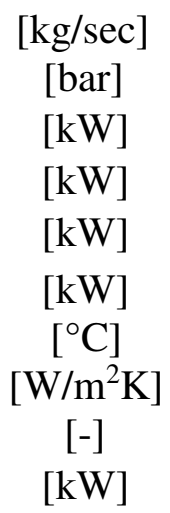

\section{REFERENCES}

1. Ruggiero, D., Waste in Europe: Production and treatment of Wastes in the European Union's Countries, pp 1-16, 2011, http://www.lteconomy.it/en/articles-en/articoli/waste-in-europe-production-and-treat ment-of-waste-in-the-european-union-s-countries, [Accessed: 05-September-2016]

2. European Commision, Being Wise with the Waste: The EU's Approach to Waste Management, pp 1-16, 2010.

3. Arena, U., Process and Technological Aspects of Municipal Solid Waste Gasification, Waste Management, Vol. 32, No. 4, pp 625-639, 2012, https://doi.org/10.1016/j.wasman.2011.09.025

4. Boudghene Stambouli, A. and Traversa, E., Solid Oxide Fuel Cells: A Review of an Environmentally Clean and efficient Source of Energy, Renewable and Sustainable Energy Reviews, Vol. 6, No. 5, pp 433-455, 2002, https://doi.org/10.1016/S1364-0321(02)00014-X

5. Møller, C. B., Design and Optimization of an Integrated Biomass Gasification and Solid Oxide Fuel Cell System, Ph.D. Thesis, Technical University of Denmark, Copenhagen, Denmark, 2010.

6. Al-Sulaiman, F. A., Trigeneration: A Comprehensive Review based on Prime Movers, International Journal of Energy Research, Vol. 35, No. 3, pp 233-258, 2011, https://doi.org/10.1002/er.1687

7. do Espirito Santo, D. B., Performance Evaluation of an Electricity Base Load Engine Cogeneration System, International Journal of Energy Research, Vol. 34, No. 9, 2009, https://doi.org/10.1002/er.1592

8. Li, S. and Wu, J. Y., Theoretical Research of a Silica Gel-water Adsorption Chiller in a Micro Combined Cooling, Heating and Power (CCHP) System, Applied Energy, Vol. 86, No. 6, pp 958-967, 2009, https://doi.org/10.1016/j.apenergy.2008.09.016

9. Teopa Calva, E., Picon Nunez, M., Rodriguez Toral, M. A., Thermal Integration of Tri-generation Systems, Applied Thermal Engineering, Vol. 25, No. 7, pp 973-984, 2005, http://dx.doi.org/10.1016/j.applthermaleng.2004.06.022

10.Ziher, D. and Poredos, A., Economics of a Trigeneration System in a Hospital, Applied Thermal Engineering, Vol. 26, No. 7, pp 680-687, 2006, http://dx.doi.org/10.1016/j.applthermaleng.2005.09.007

11. Schroeder, A., Lach, J. and Poskrobko, S., Production of Ice Water in a Tri-generation Centralized System, Archives of Thermodynamics, Vol. 28, No. 4, pp 41-62, 2007.

12. Poredos, A., Kitanovski, A. and Tuma, M., The Energy Efficiency of Chillers in a Trigeneration Plant, Forschung im Ingenieurwesen/Engineering Research, Vol. 67, No. 1, pp 40-44, 2002, https://doi.org/10.1007/s10010-001-0071-y 
13. Malico, I., Carvalhinho, A. P. and Tenreiro, J., Design of a Trigeneration System using a High-temperature Fuel Cell, International Journal of Energy Research, Vol. 33, No. 2, pp 144-151, 2009, https://doi.org/10.1002/er.1430

14. Weber, C., Koyama, M. and Kraines, S., $\mathrm{CO}_{2}$ Emissions Reduction Potential and Costs of a Decentralized Energy System for providing Electricity, Cooling and Heating in an Office-building in Tokyo, Energy, Vol. 31, No. 14, pp 2705-2725, 2006, https://doi.org/10.1016/j.energy.2005.12.003

15. Shaolin Ma, Jiangfeng Wang, Zhequan Yan, Yiping Dai and Bingheng Lu, Thermodynamic analysis of a New Combined Cooling, Heat and Power System driven by Solid Oxide Fuel Cell based on Ammonia-water Mixture, Journal of Power Sources, Vol. 196, No. 20, pp 8463-8471, 2011, https://doi.org/10.1016/j.jpowsour.2011.06.008

16. Bellomare, F. and Rokni, M., Integration of Municipal Solid Waste Gasification Plant with Solid Oxide Fuel Cell and Gas Turbine, Journal of Renewable Energy, Vol. 55, 2013, https://doi.org/10.1016/j.renene.2013.01.016

17. Rokni, M., Thermodynamic analyses of Municipal Solid Waste Gasification Plant Integrated with Solid Oxide Fuel Cell and Stirling Hybrid System, Journal of Hydrogen Energy, Vol. 40, No. 24, pp 7855-7869, 2015, https://doi.org/10.1016/j.ijhydene.2014.11.046

18. Belgiorno, V., De Feo, G., Della Rocca, C. and Napoli, R. M. A., Energy from Gasification of Solid Wastes, Waste Management, Vol. 23, No. 1, pp 1-15, 2002, https://doi.org/10.1016/S0956-053X(02)00149-6

19. Doherty, W., Reynolds, A. and Kennedy, D., Aspen Plus Simulation of Biomass Gasification in a Steam Blown Dual Fluidized Bed, Dublin Institute of Technology, Dublin, Ireland, 2013.

20. Begum, S., Rasul, M. G., Akbar, D. and Ramzan, N., Performance analysis of an Integrated Fixed Bed Gasifier Model for different Biomass Feedstocks, Energies, Vol. 6, No. 12, pp 6508-6524, 2013, https://doi.org/10.3390/en6126508

21. Keche, A. J., Gaddale, A. P. R. and Tated, R. G., Simulation of Biomass Gasification in Downdraft Gasifiers for different Biomass Fuels using Aspen Plus, Clean Techn. Environ. Policy, Vol. 17, No. 2, pp 465-473, 2015, https://doi.org/10.1007/s10098-014-0804-x

22. Amos, W. A., Report on Biomass drying Technology, National Renewable Energy Laboratory, US Department of Energy, 1998.

23. Chih-Shan, L. and Jeng, F. T., Physical and Chemical Composition of Hospital Waste, Cambridge Core, Vol. 14, No. 3, pp 145-150, 1993, https://doi.org/10.1086/646700

24. Gidarakos, E., Havas., G. and Ntzamilis, P., Municipal Solid Waste determination supporting the integrated Solid Waste Management System in the Island of Crete, Waste Management, Vol. 26, No. 6, pp 1-12, 2005, https://doi.org/10.1016/j.wasman.2005.07.018

25. Ayala, R. E. and Venkataramani, V. S., Advanced Sorbent development Program: Development of Sorbents for moving Bed and Fluidized Bed Applications, US Department of Energy, Federal Energy Technology Centre, 1998.

26. Le Coq, L. and Duga, A., Gas treatment Unit for Small Scale Gasification Application to IC Engine Gas Quality Requirement, Journal of Applied Fluid Mechanics, Vol. 5, No. 1, pp 95-103, 2012.

27. Toonssen, R., Sustainable Power from Biomass, Ph.D. Thesis, Technical University of Delft, Delft, The Netherlands, 2010.

28. Aravind, P. V. and de Jong, W., Evaluation of High Temperature Gas Cleaning Options for Biomass Gasification Options for Biomass Gasification Product Gas for Solid Oxide Fuel Cells, Progress in Energy and Combustion Science, Vol. 38, No. 6, pp 737-764, 2012, https://doi.org/10.1016/j.pecs.2012.03.006 
29. Nagel, F.-P., Electricity from Wood through the Combination of Gasification and Solid Oxide Fuel Cells, Ph.D. Thesis, ETH, Zurich, Switzerland, 2008.

30. Lee, J. and Feng, B., A Thermodynamic Study of the removal of $\mathrm{HCl}$ and $\mathrm{H}_{2} \mathrm{~S}$ from Syngas, Frontiers of Chemical Science and Engineering, Vol. 6, No. 1, 2012, https://doi.org/10.1007/s11705-011-1162-4

31. Zhang, W., Croiset, E., Douglas, P. L., Fowler, M. W. and Entchev, E., Simulation of a Tubular Solid Oxide Fuel Cell Stack using Aspen Plus Unit Operation Models, Energy Conversion Management, Vol. 46, No. 2, pp 181-196, 2005, https://doi.org/10.1016/j.enconman.2004.03.002

32. Doherty, W., Reynolds, A. and Kennedy, D., Computer Simulation of a Biomass Gasification Solid Oxide Fuel Cell Power System using Aspen Plus, Energy, Vol. 35, No. 12, pp 4545-4555, 2010, https://doi.org/10.1016/j.energy.2010.04.051

33. Somers, C., Simulation of Absorption Cycles for Integration into refining Processes, M.Sc. Thesis, University of Maryland, Maryland, USA, 2009.

34. Thermal Environmental Conditions for Human Occupancy, American Society of Heating, Refrigerating and Air Conditioning Engineers, 2004.

35. Ghirardo, F., Santin, M., Traverso, A. and Massardo, A., Heat Recovery Options for On-board Fuel Cell Systems, Journal of Hydrogen Energy, Vol. 36, No. 13, 2011, https://doi.org/10.1016/j.ijhydene.2011.01.111

36. Ajesh, S. and Kempegowda, K., Economic analysis of combined Cycle Biomass Gasification fuelled SOFC Systems, Proceedings from International Conference on Future Environment and Energy, China, 2011.

37. Itarte, M. J., Techno Economy analysis of distinctive Hybrid Solid Oxide Fuel Cells based Power Plants, M.Sc. Thesis, Technical University of Denmark, Lyngby, Denmark, 2015.

38. Gassner, M. and Marechal, F., Thermo-economic Process Model for Thermochemical Production of SNG from Lignocellulosic Biomass, Biomass and Bioenergy, Vol. 33, No. 11, pp 1587-1604, 2009, https://doi.org/10.1016/j.biombioe.2009.08.004

39. Bejan, A., Tsatsaronis, G. and Moran, M., Thermal Design and Optimization, Wiley, 1995.

40. Arsalis, A., Thermo-economic modeling and Parametric Study of Hybrid Solid Oxide Fuel Cell-Gas Turbine-Steam Turbine Power Plants ranging from 1.5 to $10 \mathrm{MW}$, Ph.D. Thesis, Virginia Polytechnic Institute and State University, Blacksburg, Virginia, USA, 2007.

41. Florio, M., Guide to Cost-benefit analysis of investment Projects, European Commission.

42. Huang, Y., Biomass fuelled Tri-generation System in Selected Buildings, Energy Conversion and Management, Vol. 52, No. 6, pp 2448-2454, 2011, http://dx.doi.org/10.1016/j.enconman.2010.12.053

43. European Commission, Access to Electricity Prices by User, http://ec.europa.eu/eurostat/CHCPm/table.do?tab=table\&init=1\&language=en\&pco $\mathrm{de}=$ ten00117\&plugin $=1$, [Accessed: 01-June-2015]

44. Granryd, E., Refrigerating Engineering, Royal Institute of Technology, KTH, Stockholm, Sweden, 2011. 